\title{
Translanguaging-as-Resource: University ESL Instructors' Language Orientations and Attitudes Toward Translanguaging
}

\author{
Jennifer Burton E Shakina Rajendram
}

This article explores university English as a Second Language (ESL) instructors' attitudes toward translanguaging in the classroom and possible reasons for instructors' resistance in moving translanguaging ideology into English language teaching pedagogy. Many researchers have forwarded translanguaging as a theoretical and pedagogical approach to language education because of its potential cognitive, social, and affective benefits. A translanguaging pedagogy calls for instructors to affirm the dynamic and diverse language practices that multilingual students utilize as part of their unitary language repertoire. However, because English-only pedagogies, policies, and practices still permeate the ESL classroom, it is critical to understand how ESL instructors' language ideologies and orientations play a role in shaping their pedagogical practices and classroom language policies. Using Ruíz's orientations in language planning and translanguaging theory, this study examined the language orientations of five ESL instructors at a major Canadian university based on qualitative data gathered through semistructured interviews. The findings provide insights into instructors' attitudes toward translanguaging, the relationship between instructors' language learning experiences and their classroom language policy, and institutional opportunities and constraints.

Le présent article explore les attitudes des professeurs d'anglais langue seconde (ESL) au niveau universitaire face au translangagisme en salle de classe ainsi que les raisons possibles de leur résistance à l'introduction de l'idéologie translangagière dans la pédagogie de l'enseignement de l'anglais. De nombreux travaux de recherche renvoient au translangagisme comme démarche théorique et pédagogique d'enseignement des langues en raison de ses avantages cognitifs, sociaux et affectifs. La pédagogie translangagière invite les professeurs à soutenir le dynamisme et la diversité des pratiques langagières que les étudiantes et étudiants multilingues utilisent déjà dans le cadre de leur répertoire linguistique unitaire. Toutefois, puisque l'enseignement de l'anglais langue seconde en classe reste imprégné de pédagogies, de politiques, et de pratiques exclusivement anglophones, il est essentiel de comprendre le rôle que jouent les idéologies et les orientations des professeurs d'anglais langue seconde dans la formation de leurs pratiques pédagogiques et de leurs politiques d'enseignement en classe. S'inspirant des orientations de Ruiz en matière de planification langagière et de théorie translangagière, la présente étude examine les orientations linguistiques de cinq 
professeures et professeurs d'anglais langue seconde dans une grande université canadienne à l'aide de données qualitatives recueillies dans le cadre d'entrevues semi-structurées. Les conclusions de l'enquête aident à mieux comprendre les attitudes des professeurs face au translangagisme, la relation entre les expériences d'apprentissage langagier des professeurs, et leur politique langagière en classe ainsi que les possibilités et les contraintes institutionnelles.

KEYWORDS: English as a Second Language, ESL, higher education, translanguaging, language orientations, instructor attitudes

\section{Introduction}

The internationalization of higher education - driven by political, economic, and sociocultural dimensions (Maringe, 2010) - has resulted in a steady increase in the number of linguistically and culturally diverse students in Canadian educational institutions. In 2017, there were 494,525 international students enrolled at all levels of study in Canada, which was a $119 \%$ increase in international student enrollment from 2010, and a 20\% increase from 2016 (Canadian Bureau for International Education, 2018). The steady increase in the number of international students enrolled in higher education in Canada has resulted in growing diversity in the linguistic and cultural landscapes of Canadian educational institutions (Dagenais, 2013), and calls for pedagogies that are responsive to the dynamic and flexible language practices of multilingual students.

However, despite growing diversity in higher education, "deep-rooted ideologies of linguistic purism" (Lin, 2013, p. 521) continue to perpetuate institutional spaces. The commodification of English language teaching (Heller, 2003) and the strict English language requirements of many universities may put pressure on language instructors to improve students' English language proficiency so that students fulfill the English language requirements of the university. Many universities in Canada offer short-term English as a Second Language (ESL) and English for Academic Purposes (EAP) programs for international students who wish to learn English in a foreign country such as Canada, as these international students "represent attractive resources to be tapped as consumers of its programmes (or products)" (Shin, 2016, p. 511). These programs have implications for language learning and teaching, as Lin (2013) states,

... language learning and teaching has become a transaction of teachers passing on a marketable set of standardized knowledge items and skills to students. This transaction is what takes place instead of seeing language learning and teaching as having both teachers and students engaged in the fluid co-creation of diverse language 
resources appropriate for situated social practices that are meaningful to both parties. (p. 525)

Language learning as a transaction may have ideological and pedagogical implications for instructors, shaping the way instructors think about and position their students' languages in the classroom. For example, even if instructors feel the imperative to create a space for their students' first language (L1) in the classroom, the commercialization of English might contribute to instructors believing that the use of the L1 could hamper students' progress in learning English especially if instructors believe greater exposure to the target language (TL) is synonymous with increased language proficiency. This belief has continued to perpetuate monolingual approaches to English language teaching (Cummins, 2007), which assume that only the TL should be used in instruction, without recourse to students' L1, and there is no place for translating between the TL and L1 in the language classroom.

In contrast to the monolingual approach, scholars who operate from a translanguaging theory of language explore the use of pedagogies that encourage learners to draw on all their language resources to communicate and make meaning (e.g., Canagarajah, 2011; García \& Li Wei, 2014; Mazak, 2017; Otheguy, García, \& Reid, 2018). Scholars have articulated a translanguaging pedagogy as involving planning and structuring teaching strategies that build on multilingual students' entire linguistic repertoire as a resource in their learning. While research has discussed the potential of a translanguaging pedagogy in supporting students' comprehension of complex texts and content, helping them to develop a better understanding of their language learning, and expanding their communicative repertoires (García, 2009), there is still a gap between translanguaging as a concept and translanguaging as a practice (Canagarajah, 2011), particularly in the higher education context. We believe that one way of closing this gap and implementing translanguaging as an effective pedagogy is to address instructors' underlying attitudes toward language diversity in their classrooms. Richardson (1996) notes the importance of instructors' attitudes in understanding classroom practices, and Rivera and Mazak (2017) stress the need to examine attitudes toward translanguaging because they can determine how effective a translanguaging pedagogy is. For the purpose of our article, we use the term attitude to refer to an "individual's orientation toward an item, person, concept, institution, social process, or situation, and is indicative of [their] web of beliefs and perceptions" (Finch, 2012, p. 369). Our study aims to shed light on instructors' attitudes by examining their language orientations, and their beliefs and perceptions about the role of translanguaging in the classroom. Our study asks three questions:

Research Question 1: How do instructors view and position translanguaging in the English language teaching and learning context? 
Research Question 2: How do instructors enact informal language policy in their reported classroom practices?

Research Question 3: How do instructors' linguistic background and personal language-learning experience play a role in their attitudes and reported practices?

\section{Theoretical Framework}

\section{Translanguaging}

Translanguaging is a theoretical reconceptualization of language that posits that multilingual learners have only "one linguistic repertoire from which they select features strategically to communicate effectively" (García, 2012, p. 1). For García and Li Wei (2014), translanguaging is not merely the mixing of separate named languages. Neither is it something that multilinguals do only when they lack the necessary vocabulary to express themselves monolingually. Rather, when students use more than one language in communication, they are selecting language features from their overall repertoire in ways that help them fulfill their communicative needs and assert their linguistic and cultural identities. The idea of a language repertoire (Otheguy, García, \& Reid, 2015) transcends traditional conceptualizations of language, and disrupts the notion of languages as discrete, bounded systems. It recognizes all of language users' fluid language and multimodal practices as part of an integrated meaning-making system. From the perspective of translanguaging theory then, language teaching can be seen not as a linear process, whereby teachers add autonomous languages such as English to their students' existing repertoires. Rather, language teaching can be viewed as a dynamic process that engages students' multiple meaning-making resources (Mazak, 2017). Thus, within this perspective, the role of educators would be to "engage in complex discursive practices that include all the language practices of students in order to develop new language practices and sustain old ones, communicate appropriate knowledge, and give voice to new sociopolitical realities by interrogating linguistic inequality" (García \& Kano, 2014, p. 261). By doing so, educators can disrupt the socially constructed language hierarchies that prevent multilingual ESL students from using their entire language repertoire (Otheguy, García, \& Reid, 2015).

The adoption of a translanguaging pedagogy involves instructors helping their learners to become more aware of their entire linguistic repertoire, and how to use the various features of their repertoire for different situations, purposes, and tasks is emblematic of this translanguaging pedagogy (Wiley \& García, 2016). According to García, Johnson, and Seltzer (2017), the specific core components of a translanguaging pedagogy include (a) a translanguaging stance, which is the belief that the diverse language practices of 
students are valuable resources that should be used in the classroom; (b) a translanguaging design, which involves the design of strategic plans (e.g., lesson plans, assessments) that are informed by students' diverse language practices; and (c) translanguaging shifts, which require the ability to make moment-by-moment changes to the lessons according to students' needs. The concept of a translanguaging stance is particularly relevant to our study as we believe that a translanguaging pedagogy requires that instructors adopt a translanguaging stance toward their students' diverse linguistic repertoires (Bailey \& Marsden, 2017; Deroo \& Ponzio, 2019; García, Johnson, \& Seltzer, 2017; Haukås, 2016).

\section{Orientations in Language Planning}

Our study also draws on Ruíz's (1984) orientations in language planning. Ruíz proposed three basic orientations toward language as a way of guiding critical analysis and reflection about "what is thinkable about language in society" (p. 16). A language-as-problem orientation assumes that students who are not proficient in a dominant language are deficient in their ability to learn. Ruíz (1984) suggests that the language-as-problem orientation is an influential discourse in English-dominant countries wherein a lack of proficiency in English is seen as a problem. A language-as-right orientation sees students as having the personal, human, and legal right to maintain their heritage language. A language-as-resource orientation promotes the language competencies of multilingual speakers as resources for social, cultural, economic, and political gains.

Critiques of Ruíz's orientations have argued that the orientations are limited in their analytical usefulness because first, they are not reflective of the reality of current policy situations, and second, language planning and policy in practice are usually influenced by a variety of forces that include political expediency and extralinguistic social issues, and so it would be difficult to identify discrete orientations behind a language policy (e.g., Bale, 2016; Crawford, 1998; Ricento, 2005). However, Hult and Hornberger (2016) assert that the orientations are useful as analytical tools to identify and analyze the discourses surrounding language in specific policy contexts. They add that Ruíz's orientations can be used by researchers as etic concepts to analyze the values that are expressed in policy debates and negotiation, and also as emic concepts to guide analysis about the beliefs that are expressed by people about the role of language. In line with Hult and Hornberger's (2016) suggestions, we use Ruíz's language orientations, with translanguaging theory, to analyze ESL instructors' attitudes toward language learning and translanguaging, and the language policies that they enact in their classrooms. Like Menken and García (2010), we believe that all instructors are policy makers who interpret, negotiate, resist, challenge, (re)structure, and enact lan- 
guage policies through their attitudes about language and their pedagogical practices.

\section{Literature Review}

Research on translanguaging conducted in the field of bilingual education has suggested that it is a valuable resource for learning. The reported benefits of translanguaging in the literature (e.g., Carroll \& Sambolín Morales, 2016; Duarte, 2016; García, Johnson, \& Seltzer, 2017; García \& Li Wei, 2014; Wiley \& García, 2016) include building background knowledge, promoting a fuller understanding of the subject matter, developing higher order thinking skills, building metacognitive ability, engaging learners in identity investment, and interrogating linguistic inequality. Translanguaging as a pedagogical practice has also been shown to be advantageous specifically for second language (L2) learning, for example, by enabling cross-linguistic transfer, promoting collaborative language learning, and helping students develop a more critical understanding of language and culture (e.g., Bono \& Stratilaki, 2009; French, 2016; Rajendram, 2019).

Although many studies have focused on the pedagogical value of translanguaging in the English language classroom, research on the attitudes of instructors toward translanguaging in higher education contexts is scarce. Studies that do investigate instructors' attitudes have found that they often experience tensions related to how often, when, where, and why they should use translanguaging in the classroom (Carroll \& Sambolín Morales, 2016). While some instructors may recognize the value of translanguaging, they usually believe that it should be targeted to specific tasks, situations, and proficiency levels (Hussein, 2003; Storch \& Wigglesworth, 2003; Tan, 2017). Tan's (2017) study suggests that the tensions instructors experience in using translanguaging practices are mainly due to their concern that using languages other than English could be counterproductive to their goal of preparing students to become successful in their English language environment.

The dearth of scholarship on instructors' attitudes toward translanguaging does not negate translanguaging as a demonstrably effective way to organize teaching, particularly in the higher education context. Drawing on ethnographic data from two different educational contexts, Hornberger and Link (2012) argue that "the welcoming of translanguaging in classrooms is not only necessary, but desirable educational practice" (p. 239). If instructors are able to see the benefits that translanguaging pedagogy has on their students, instructors may develop a more willing attitude to adopt a translanguaging stance and approach to language teaching. Like García, Johnson, and Seltzer (2017), we believe that translanguaging pedagogy involves a translanguaging stance, and propose that a closer examination of instructors' language orientations and attitudes will provide valuable insights into possibilities for translanguaging in higher education. 
The instructor-student relationship is critical in understanding the conceptualization of translanguaging pedagogy. Ke and Lin (2017) provide the rationale for a translanguaging approach in English language teaching. They make reference to a key consideration: the shift in the role of the language teacher from "providing linguistic knowledge and skills to building learners' self-learning capacity, learner agency and L2 identities" (p. 33). In a study examining the translingual identities of international graduate students in a U.S. university ESL classroom, Kim (2017) reported that restrictive monoglossic language ideologies led to disempowered and racialized student identities. A translanguaging pedagogy challenges instructors who want to separate languages by controlling what languages are spoken in class to reimagine their role in the classroom (Babino \& Stewart, 2018). The instructor-student relationship in translanguaging pedagogical practices is worthy of ongoing examination to ensure that instructors remain flexible in the negotiation of their classroom language practices, positioning students at the centre (Kleyn \& García, 2019)

We understand that translanguaging ideologies call us to reexamine power differences between instructors and students in spaces like English language classrooms, especially given the potential for translanguaging to act as a transformative practice promoting social justice (García \& Leiva, 2014). Studies have shown that students feel more comfortable translanguaging with their peers behind their instructors' backs because of the power distance between them (Canagarajah, 2011). Furthermore, students who have experienced English-only instruction for many years may not feel comfortable using translanguaging with their instructors. Thus, García and Li Wei (2014) and Li Wei (2014) articulate translanguaging as a co-learning approach that changes the roles of instructors and students to that of co-constructors of knowledge who draw on their collective linguistic repertoires through a translanguaging pedagogy and policy. Due to our own positioning and the dearth of research examining instructors' attitudes toward language differences as they relate to pedagogy and policy, this study comes at a critical time when English language education in postsecondary contexts can be enriched by innovative insights into language learning strategies, curriculum, and policies informed by translanguaging.

\section{Method}

\section{Research Setting}

This study was conducted at a major Canadian university with an enrolment rate of approximately 13,000 students, of which 13\% are international students from more than 90 countries enrolled in credit programs and more than 350 students in a noncredit ESL bridging program. The ESL department at this university offers mainly academic and short-term language programs, 
and most students study on a full-time basis (21 class hr per week). The program focuses on integrating reading, writing, listening, and speaking skills in the main core class ( $15 \mathrm{hr}$ per week with one instructor). Students also take a separate skills class (6 hr per week) in either grammar and writing, or listening and speaking. Academic language and literacy is taught in the upper levels. The demographics in the ESL program mostly include international students from China and Southeast Asian countries. Upon completion of the language program, many students enter an undergraduate program usually in the Faculty of Engineering and Applied Sciences or Business Administration. In the final course in the program (called Advanced EAP), students have the option to take one undergraduate-level credit course offered by the university if the student has been conditionally accepted into a select faculty.

While there is no explicit language policy in this ESL program, Englishonly discourses circulate among students, administrators, and instructors, premised on the idea that students come to Canada to learn English, and, therefore, should be speaking as much English as possible, especially given that English is the language they are expected to use in their university classes. As such, it is pertinent to understand instructors' attitudes toward language differences in their classrooms. Given the university's priority on internationalizing the campus as indicated in their Internationalization Plan, we believe that it is important to find ways to include international students' linguistic and cultural knowledge in the university setting, and one way to account for this priority is to explore ESL instructors' attitudes toward translanguaging.

\section{Participant Background Information}

Five instructor participants took part in this qualitative study, with each participant selecting a pseudonym of their choice.

Beth is a sessional instructor with three degrees: a Bachelor of Education in Secondary English, a Bachelor of Arts in English Literature, and a Master's of Adult Education with a specialization in Second Language Acquisition. She also has a Teaching English as a Second Language (TESL) certificate and 19 years teaching experience, 14 of those years as an ESL instructor. English is her first language, and she is learning Spanish.

Carmen has a bachelor's degree in English and a master's degree in Religious Studies. She lived in Japan for 4 years where she taught conversational English. She is a permanent instructor in the ESL department with a TESL certificate. She has been teaching ESL for 15 years. She speaks English as her first language and learned some German, French, and Japanese.

Nancy has a bachelor's degree in Early Elementary Education. After volunteering with ESL, she completed a TESL program while she was a substitute teacher for the public school board. She has a Master's in Curriculum and Instruction, and the topic of her dissertation was on teacher identity and 
teaching ESL. She has been teaching ESL for 15 years, and at the time of the interview, she was a sessional instructor. She has recently been hired on as a permanent instructor. Like the other two female participants, Nancy's first language is English. She speaks some French.

Parsa speaks Farsi as his first language and English as his second. He was born in Iran where he completed his Bachelor of Education and Master's in TESL. He also has a PhD in TESL and more than 15 years ESL teaching experience. Like Nancy, Parsa has recently been hired as a permanent instructor.

John, the fifth and final participant, was born in Turkey where he completed his bachelor's degree in English Language Teaching. Like Parsa, he has a Master's degree in TESOL, as well as a Diploma in Teaching English to Speakers of Other languages (DELTA) from Cambridge University. He has been teaching ESL for more than 30 years. He is a permanent instructor at the university. His first language is Turkish, his second language is English, and he has learned some German and Korean.

\section{Data Collection}

Qualitative data for the study were gathered through semistructured indepth interviews with five ESL instructors at a major Canadian university. The participants were selected using purposeful sampling (O'Leary, 2017) in order to recruit instructors who had different L1s, language learning and education experiences, and work status, and to ensure they had more than two semesters of teaching experience at the university. Before data collection, participants were informed that the research project was about their language learning experience and classroom teaching practices and that we were particularly interested in understanding their beliefs about language teaching and learning. Instructor participation was voluntary, and they could withdraw at any time.

The interviews were conducted by one researcher who had previously worked in the language program and had professional and personal relationships with the participants in this study. The researcher's rapport with the participants allowed her to obtain more detailed descriptions and rich perspectives from them during the interviews. The interviews took place at the location of participants' choosing, either in their private work office or in their homes. The participant interviews lasted approximately 75 min each with a focus on open-ended and scenario-based questions pertaining to their teaching practices and classroom experiences.

Because the instructors in this study were not familiar with translanguaging theory, they referred to the L1/home language and L2 in our conversations with them, therefore, we adopted this terminology in our interview questions. The open-ended interview questions asked instructors directly about their current and past classroom practices; for example, do you have a policy/rule about the use of languages other than English in class? The scenario- 
based questions (Brownless, Walker, Lennox, Exley, \& Pearce, 2009) were hypothetical situations that instructors may or may not have encountered in their teaching practice; for example, you observe one student frequently using their L1 to translate words, explain instructions, and give answers to a less proficient student in class. What would you do? Both types of questions were used to elicit participants' epistemological beliefs about their classroom language practices and policies, yet it was in their response to the scenario-based questions that we observed, at times, conflicting and contradictory beliefs. As an example, while one instructor had an explicit "English only" rule, there were moments when other languages served a specific function at a particular time and place, highlighting the fluidity of language, and, in turn, language practices. The interviews were audio-recorded, transcribed, and analyzed by both researchers. During the transcription process, we made preliminary notes in the margins individually that triggered any connections to the literature and then compared notes.

We were aware that the interviewer's close relationship with the participants, and our positionality as language instructors and researchers, could influence our analysis of the interview data. Therefore, we accounted for the credibility of the analysis (Lincoln \& Guba, 1985) using the peer examination technique (Bitsch, 2005; Krefting, 1991), whereby we conducted ongoing discussions on the analysis process and challenged each other's interpretations of the data to uncover our biases and approach the analysis from multiple perspectives. We also sent the transcripts to our participants for member checking and approval. This gave participants the opportunity to remove parts of the transcript they did not feel comfortable being included in the article, and to make additions, clarifications, and revisions to the transcripts.

\section{Data Analysis}

Our analytical approach was deductive and inductive because Hult and Hornberger (2016) suggest researchers apply inductive analysis in conjunction with deductive analysis when using Ruíz's orientations as heuristic devices. The analysis occurred in stages. After transcribing the interviews, we removed our preliminary analytical notes that triggered connections to the literature and sent a clean copy of the transcribed interview to each participant. Once the participants approved their transcript, each researcher read through the five transcripts in full and identified parts of the participant's texts that pertained to the three language orientations: language-as-problem, language-as-right, and language-as-resource. This deductive approach allowed us to identify connections between participants in how they spoke about their perceptions of translanguaging in their particular classroom contexts.

In the next stage, we used inductive thematic analysis (Nowell, Norris, White, \& Moules, 2017; Thomas, 2006) to identify themes that emerged from 
the content of the data within and between each language orientation to highlight similarities and differences across the participants' narratives. At this stage, when analyzing the instructors' perspectives from the language-asproblem, language-as-right, and language-as-resource framework, we observed that participants demonstrated different language orientations based on context, student and instructor language backgrounds, language level, classroom demographics, and so forth. This observation made us consider that while translanguaging may be viewed as a right in one situation, it may be viewed as a problem in another. This realization made the distinction between each language orientation less clear for us. As such, we approached our data by asking questions such as what is significant about this participant's example? This final inductive stage of analysis allowed us to identify four themes as they related to instructor narratives about their attitudes toward language variation in the ESL classroom. These themes included (a) languages as mutually exclusive, (b) translanguaging as a resource for specific functions and proficiency levels, (c) relationship between instructors' language learning experience and classroom policies, and (d) institutional opportunities and constraints. Approaching our analysis process with a deductive and inductive lens allowed for a more comprehensive analysis of the qualitative data (Azungah, 2018).

In presenting these themes in the Findings and Discussion section below, it was less important that we had an equal balance of participant voices across each theme, as there were only five participants; instead, we aimed to report rich descriptive examples of participant experiences.

\section{Findings and Discussion}

\section{Theme One: Languages as Mutually Exclusive}

The first theme that was prevalent in the conversations with the participants relates to language positioning, specifically viewing languages in competition or conflict with one another. Several of the instructors framed English as a skill that needs to be developed over time. In reference to building vocabulary, Beth noted that students need to figure out English words by explaining them in English because this is a skill that builds their language. When John responded to being asked if he allows students to translanguage in class, he said, "It's [English] a skill. A skill means you have to practice, if you practice you do it better. If you make mistakes, it doesn't matter but you learn it that way. It is the most effective way." When English is positioned as a skill that takes time to develop, then the use of translanguaging in the ESL classroom is seen not as a resource but as an obstacle to maximizing the use of English during class time. In terms of language use outside the class, Carmen stated, "every time you use English outside of the classroom, you're moving ... closer to your goal." Our analysis suggests a language-as-problem orienta- 
tion toward translanguaging, because the use of any language other than the TL was seen as moving students backward from their goal of improving their English proficiency.

Beth explicitly mentioned students' desire to

use class to speak English ... they'll even say that they want to make more friends that are outside their first language group so that they can practice speaking English, and they identify, they say “I don't get enough practice speaking English." They often live with people from their own language group, and they're conscious of that.

According to Beth, if students did not practise speaking in English in and outside the classroom as much as they could, they would not be "stretched" in terms of their proficiency, and there was a risk of "losing" the language. Similarly, John emphasized the role English should play in his learners' lives, "English everywhere, everything you do, and you if want to cry, try to cry in English. If you want to dream, dream in English." John's exaggeration of crying and dreaming in English indicates the importance he places on English.

English use inside and outside the classroom is not necessarily synonymous with increased English proficiency (Cummins, 1991). While students have the right to use their L1, it is easy to understand that instructors may believe translanguaging to be a hindrance to their English learning when languages are positioned as competing with one another, especially given Beth's perception of her students' expressing desire to speak English. The notion of linguistic hierarchization (Phillipson, 1992), whereby specific named languages (e.g., English) and/or language varieties (e.g., Standard English) are privileged over others, is further reinforced when languages are viewed as mutually exclusive rather than coexisting in a broader ecosystem.

A student's use of translanguaging may be seen as a problem in the ESL classroom when not all students share the same linguistic background. When asked if and when it is appropriate for students to translanguage in class, Carmen shared her thoughts as follows:

I think that it is impolite for people to be using a home language that is not shared by everybody in the group, because then they're cutting one another off ... it's not appropriate ... If it's international [multiple languages], then in order to be polite ... I say you're leaving someone out and that's not polite.

Parsa echoed similar sentiments by mentioning that students will "feel isolated from that conversation." Beliefs around fairness and language equity were also expressed by John when giving an example of using his linguistic resources in class,

there is a problem when you have ... different linguistic backgrounds, it's not always a good idea, for example, if I use Arabic in 
my class [to help Arabic speakers] other students may say, "what is this teacher talking about?" so it's not a safe approach.

These results indicate that instructors' attitudes toward translanguaging may be a result of instructors' desire to create fair and equal learning environments for all students, which is promoted by the use of English and no other languages. Like Carmen, Parsa, and John, who were concerned with fairness, Nancy also strived to create a respectful learning environment for all students, and the following quote shows her attitude toward language use when she responded to the prompt about a language policy or rule in her classroom:

I also genuinely try to respect, in terms of language use, in terms of who they are and what they are bringing as individuals and I hope that they will reciprocate that and let me be who I am. I tell them ... "all languages are welcome."

Nancy viewed herself as a monolingual speaker of English, but tried to place herself in the position of her students, "I feel like if I was going to attempt to learn another language, because English is what I'm drawing from, I'm going to want to see comparisons or parallels and not necessarily translation." She continued, "if they're switching, if they're translating the language development is still happening ... I like to find out what the students want, too." Nancy provided an example of an experience teaching a short-term program where 14 of her students were from Japan and one was from Mexico,

if most of your conversation and work is happening in Japanese and she's [the Spanish speaker] is in your group, then she's going to be left out, so it's that sort of balance, but I felt like they [the students] are aware of that.

Importantly, Nancy was aware of students being left out, but rather than controlling students' language use by enforcing a strict English-only classroom policy to create fairness and equality, she placed the onus of responsibility on the students. The students became the language brokers who negotiated their own language use in the classroom, which aligns with research on translanguaging as a "naturally occurring phenomenon" (Canagarajah, 2011, p. 8) and a "natural and characteristic practice of bilinguals" (Allard, 2017, p. 116). What Nancy "fundamentally disagree[d]" with is punishing students for translanguaging in class. She did not position translanguaging as a linguistic threat to their English learning; in fact, she encouraged them to use their entire linguistic repertoire as a resource, thus, seeing translanguaging as a resource in her students' learning. 


\section{Theme Two: Translanguaging as a Resource for Specific Functions and Proficiency Levels}

While Nancy positioned translanguage as a resource for her students' learning, other instructors restricted the use of translanguaging as a resource to specific functions and proficiency level, to accomplish non-language-learning-related functions. Although most instructors had an English-only policy in place in their classes, they suggested that there were certain situations in which the use of translanguaging would be acceptable. For example, when asked about her classroom language policy, Carmen replied,

There's circumstances where it's appropriate, for instance, I would prefer that my students hear about a health advisory in their first language, in their home language, because then they're going to understand, or if it's like how to register at the university ... if it's beginner students and they're permanent residents and there's something going on with their landlord, or if we're talking about something that is real that involves them, then their home language, it's okay.

Carmen's reasons for the inclusion of translanguaging in the classroom parallel the results of many studies showing that some of the most common purposes for which instructors in L2 contexts allow the use of their students L1 are for administrative reasons, classroom management, and giving instructions (e.g., Corcoran, 2008; De la Campa \& Nassaji, 2009; Greggio \& Gil, 2007; McMillan \& Rivers, 2011; Tang, 2002). Although Carmen created a space for translanguaging in the classroom, the justification for it was based on a translanguaging-as-temporary-resource or language compartmentalization perspective rather than a translanguaging-as-resource stance. Language compartmentalization is based on the belief that students' first and second languages form distinct systems and exist separately in a learner's mind, and, thus, their languages should be designated for different functions. Instructors who adopt this perspective would "not deny the L1 of the student; instead, redirect the students' use of that language to those environments and circumstances in which it is appropriate" (Lippi-Green, 1997, p. 109). Mackinney (2016) argues that these policies represent a regulation of learners' multilingualism, and undermine their complete linguistic repertoire. In contrast, a translanguaging-as-resource stance would see all of students' languages as being an integral, inseparable part of their overall communicative repertoire (García, Johnson, \& Seltzer, 2017; Li Wei, 2018).

Although Carmen and other instructors such as Parsa accommodated the use of translanguaging for specific purposes such as administration and giving instructions, they limited this only for their beginner classes or students with lower proficiency levels. Carmen clarified that 
for beginners, I allow them to use their home languages to translate directions so that we [the students] know what's going on ... but once we get into intermediate or advanced, then I tell them to use their English to solve problems.

When Parsa was asked if he used other languages in the class when he was teaching English, he explained,

When I have to [allow translanguaging] in lower levels, yeah, but normally no. Higher level students do not really need, they don't have problems in understanding the class, so when they speak their first language, I usually discourage them because there's no reason for them to use their first language in class when they can communicate in English. In lower level classes, sometimes it would be okay.

Research on translanguaging in many ESL contexts suggests that both the instructors' and students' perceptions toward the usefulness of translanguaging seem to hinge on students' proficiency levels (e.g., Ahmad, 2009; Adamson \& Fujimoto-Adamson, 2012; McMillan \& Rivers, 2011). A common perception among instructors in these contexts was that students should be allowed to translanguage when they are at the beginning stages of their language learning, but that translanguaging should be discouraged or disallowed once they have attained an advanced level of English proficiency (Tamimi Sa'd \& Qadermazi, 2015). Similarly, studies on instructors' own use of translanguaging in their teaching show that there are significant decreases in the frequency of their translanguaging as the proficiency level of their students increases (Qian, Tang, \& Wang, 2009; Greggio \& Gil, 2007; Meiring \& Norman, 2002). In some cases (e.g., Ahmad, 2009), students in higher proficiency classes prefer or request that their instructors adopt an English-only policy because they believe that translanguaging will not help them to improve their English language proficiency. In Beth's detailing of her students' language preferences, she suggested that even students in her beginner classes share the same concern about the use of translanguaging:

I think quite a few of them are motivated not to [translanguage] because they often see their weakest area as speaking fluently and they're looking for opportunities to speak English ... next semester they'll be going in to regular English classes, and they're very conscious of their language limitations, so they're wanting to use class to speak English.

Underlying students' and instructors' belief that translanguaging is only useful when students are at lower proficiency levels is a language-as-problem orientation toward translanguaging, because it sees the use of any language other than the TL as a hindrance to achieving advanced "native-like" English proficiency. However, proponents of translanguaging stress that it can help 
instructors ensure that all students, regardless of their proficiency levels in their L1 or in English, are able to draw on their entire knowledge base and skill set, and thereby learn more effectively (Hesson, Seltzer, \& Woodley, 2014).

\section{Theme Three: Relationship Between Instructors' Language Learning Experience and Classroom Policies}

Another theme arising from our study relates to the relationship between instructors' language learning experiences and their classroom language policies. While learning English, Parsa tried using translanguaging, for example, to find the translation of difficult English vocabulary, but found that it complicated his learning process. He explained, "I found it difficult because you're doing two languages at a time ... you're decoding a language and then encoding it to another language ... that adds to the process." Guided by this language-as-problem orientation, Parsa did not allow his students to use any languages other than English because, as he said, "they will be relying on their first language more which doesn't help." However, instead of enforcing an official English-only policy, he tried to prevent them from translanguaging by standing close to them or using humour. Like Parsa, John's classroom language policy and views on language learning were also influenced by his own difficulties learning English. When asked if John would let his students brainstorm some of their ideas in an outline by translanguaging, he explained,

I suffered a lot while I was learning a language. So I have to say, I understand an ESL student much better than native teachers ... . Sometimes most of the students don't understand what the students want to say, even teacher do not understand, but I got it, I understand [them: students] . . . because that was the same situation with me ... I suffered a lot, that's a kind of advantage for me, I make use of that. From my experience I have learned, you have to learn English, you have to use English.

Although John shared the same first language as several students in his class, he mainly chose not to use that language when communicating with them. John believed that just as the struggles he faced learning English gave him an advantage over "native teachers," using only English will be advantageous for students because it will make them more resilient and help them become better learners - "if they're [the students are] going to suffer, they should all suffer together, that makes them stronger." Similarly to John, Beth identified with the struggles her students face learning a new language because of her own experience learning a foreign language where she felt that she was "put back into a helpless position." Talking about her language learn- 
ing experience in relation to her approach to her English language teaching, she said,

We talk about language being an integral part of your identity, and you're actually shedding your identity and going back to, almost like a child, where you feel very helpless because you want to perform an everyday thing but you don't have even the language that you need to ask somebody for directions . . . it makes you not want to put yourself in a position where you have to try and speak the language, it's a real stretch, so I understand how they feel more. I can empathize more because of that recent experience.

Although Beth empathized with her students because of the challenges she experienced, she believed that the only way for her students to overcome those challenges and "progress faster in a language [English]" is to "use the language at every opportunity you can get." Thus, Beth's classroom policy was based on a theme she introduces her students to at the beginning of every semester: "LYLIE . . . Live your Life in English." Although she did not have an official English-only policy in place, she explained that when she heard students translanguaging, she asked them, "How are you living your life in English?" and reminded them "Let's be LYLIES here for a while." Beth also explained that she "tr[ies] more not to respond in a negative fashion when they're speaking their first language" but that she was there to continue to remind them to make the most of their opportunity to speak English. Underlying the assumptions behind Beth's language-as-problem orientation toward translanguaging in students' learning is the maximum exposure hypothesis (Cummins, 2001), which presupposes that minority English language learners need as much exposure to the TL as they can so that they gain proficiency and confidence in it. However, this hypothesis has been debunked by Cummins (2001) through research proving that teaching learners for all or part of a school day through a minority language does not have any negative consequences for the development of their academic English skills.

While Beth likens learning a language to "shedding your identity," Carmen and Nancy believe that the first language is an inseparable part of students' identity, and, thus, it is their right to use the language (Cummins, 2001; McMillan \& Rivers, 2011). Carmen believes that when she encourages students to draw on the benefits of translanguaging, for example, by using their devices to find translations of English words, "I'm levelling the playing field. I'm bringing their identity into the classroom because I'm saying, your language is important . . . it's okay, we're not shunning your language." Carmen believes that the access to translanguaging gives students "more authority in the class" and "they can input more into the class because they've got more language." Carmen's reasons for the inclusion of translanguaging in the classroom are consistent with Cummins et al.'s (2006) and McMillan and 
Rivers' (2011) assertions that making a space for students' home languages fulfills important identity and cognitive functions.

Nancy, also a proponent of translanguaging, sees translanguaging as a resource because of her own experiences learning a foreign language as an elective in university, where she shared the same L1 (English) as her language instructor. Recalling her language learning experiences, Nancy says,

I was never forced to survive in the class with the little language I knew, I always had my language resources to use and I asked my teacher in English, right, and I shared the same first language as my teacher ... We have so many students who seem to have preference of a native English speaking teacher, and I think "oh my gosh, you're so better off with someone who's a non-native English speaking teacher because of how they've learned, how they understand the language, they are going to be able to answer questions with an awareness that I don't have."

As illustrated in her quote above, Nancy feels that being an L1 speaker of English is a "deficit as a language teacher" because she is unable to understand the language learning process in the same way that her multilingual students can. Interestingly, instructors such as Nancy and Carmen who are L1 speakers of English and considered themselves mainly monolingual see the use of translanguaging as a resource for students' learning, while instructors who learned English as an L2 (Parsa and John) discourage translanguaging as they see it as a problem that could hinder students from becoming proficient English speakers.

\section{Theme Four: Institutional Opportunities and Constraints}

The fourth theme considered institutional constraints that impact classroom language policies and practices; one constraint is time. Beth acknowledged that students are "paying huge amounts of money to improve their English as fast as possible." She commented on the pressure of time: "the expectation is for them to learn so many new words so quickly, and they don't, they forget them because they don't have the time needed to start using them." As such, she encourages students to take advantage of every opportunity to speak English in class in order to "incorporate [vocabulary words] into their language so they become internalized." Here, Beth views vocabulary internalization as occurring with practice in the TL. Similarly, John spoke about using his time wisely: “There's no time, you shouldn't be killing your time describing the meaning of avocado with 100 words ... it's very practical to use their own language." Considerations of time impact instructors' attitudes and choices to permit translanguaging in the classroom.

Schissel, De Korne, and López-Gopar (2018) remind us that regardless of instructors' attitudes, they may be restricted by "language politics in their 
education contexts" (p. 13). Instructors face opportunities and constraints in curriculum-related institutional structures. Beth who is a sessional instructor in the university, and Parsa who, until very recently, was also a sessional instructor there, made reference to their limitations to make curriculum and pedagogical changes due to their position and status within the organization. John, a permanent instructor in the university who is in a position to effect curriculum change, has this to say:

but one thing [the ESL program is] ignoring is needs analysis, there is no communication between the departments ... for example, someone from our department should approach them [another department] and say "we are sending students to your department, what are their weaknesses?" so that we can take their weaknesses and then blend our curriculum or whatever we do in our department. There is no such thing.

In this example, John's references to students' needs analysis is important in understanding the relationship between language as taught in ESL programs and language as needed in undergraduate programs. This example highlights the ways in which language suffers from disciplinary divides (Sembiante, 2016), and ultimately calls for a more comprehensive explication of roles and responsibilities, and language practices and policies within and between programs and disciplines in institutions of higher education. For instance, if language is viewed not as a social practice but rather as a skill that students acquired to successfully function in an undergraduate class, then it may be easy for content course instructors not to assume responsibility for students' language-related concerns. Likewise, if ESL instructors do not consider the disciplinary literacy practices (Hansen, 2000) of their students, then it may be easy for ESL instructors to position or view themselves as solely language instructors, as though language can be separated from content. A monolingual lens to language teaching separates languages into discrete systems, and, thus, demarcates boundaries for which languages are appropriate in which spaces. This can explain why it might be challenging for educators to reconceptualize language from a translanguaging lens; a students' multilingual repertoire is not understood as a resource, but, instead, is positioned as a problem in the ESL classroom. Well-established institutional practices and power dynamics impact what and how languages are viewed and taught, as well as influence decisions related to curriculum content. That said, reimagining new possibilities for language practices in higher education-beyond the walls of ESL classrooms, for example - that "stimulate and develop [students'] multilingual competence" (Caruso, 2018, p. 65) is critical in promoting and sustaining translanguaging practices in institutional spaces in Canadian universities. 


\section{Conclusion and Implications}

This study uncovered some of the tensions in carrying forward translanguaging ideologies into classroom pedagogy in the context of ESL programs in higher education. In closing the gap between translanguaging as a concept to translanguaging as a practice, instructors need to take on a holistic reconceptualization of language, and see language speakers, the languages they speak, and their linguistic repertoires through an entirely new lens (Canagarajah, 2011; Cenoz, 2017). Our research reveals that even when instructors in ESL classrooms accommodate the use of translanguaging, their decisions can still be viewed through a monolingual lens - rather than a translanguaging lensbecause the students' discursive language practices were not actively encouraged and taken into account at the onset of the lesson design. This means that "monolingual and standardized language ideologies ... continue to inform policy and practice" (Kubota \& Miller, 2017, p. 130). A predominant theme in our findings was that translanguaging tended to be perceived as slowing students' English learning instead of being perceived as a resource that can deepen their understandings and extend their knowledge (García \& Li Wei, 2014). Even when instructors have a language-as-resource orientation toward translanguaging, it was often viewed as a temporary resource to accomplish specific functions in lower proficiency classes. The belief that a students' L1 and English are not complementary but function independently from each other has been labelled a "monolingual view of multilingualism" (Grosjean, 1982), which does not consider the complex, integrated language practices of multilingual ESL students. Instructors made distinctions between students' L1 and L2 throughout their interview responses. These distinctions pose a challenge for researchers and practitioners working within the broader field of language teaching in higher education because languages are still positioned and taught as separate, discrete, bounded systems, which is in direct contestation to translanguaging theory, which reconceptualizes language as part of a unitary linguistic system. As such, we believe that in adopting a translanguaging belief, alternative ways of speaking about languages beyond the language separation terminology (e.g., L1/L2) is needed.

Furthermore, when translanguaging is treated as a temporary scaffold to develop skills in English, teaching and learning remains focused on the mastery of English, rather than the development of multilingual proficiencythereby reinforcing a structuralist approach to teaching language as a set of skills the learner acquires, rather than a social practice (Pennycook, 2010). Underpinning this language teaching approach is a monolingual language ideology that views proficiency in English as the ultimate goal of language learning. As De Jong (2016) argues, the language-as-resource orientation, like the language-as-problem and language-as-right orientations, tends to default to a primary focus on one language being positioned as a resource within a competitive frame (English vs. the L1). 
We propose that to move away from a monolingual and competitive ideology of languages and enact a translanguaging pedagogy where "both languages are used in a dynamic and functionally integrated manner" (Lewis, Jones, \& Baker, 2012, p. 652), educators need to adopt not a language-asproblem or an English-as-resource orientation, but rather a translanguaging-as-resource orientation toward their learners' linguistic repertoire. This theoretical shift repositions the mutual exclusivity of languages, challenging instructors' beliefs that all the language practices and features of a learner's overall language repertoire cannot function together to enhance students' learning. Instead, a translanguaging-as-resource orientation would consider all the language practices that form students' repertoires as an integrated system, and weave students' diverse repertoires into the classroom as important resources in their development of multilingual competence. This perspective complements what García, Johnson, and Seltzer (2017) call a translanguaging stance, which is a belief that languages should not be positioned as separate, but, rather, are coexisting in one linguistic repertoire. In this sense, students can draw upon their rich linguistic repertoires to make connections and associations during their English learning process. By positioning students' multiple languages as coexisting and supporting rather than competing with one another, instructors can establish equity for learners in the classroom. Furthermore, we believe that a translanguaging stance requires researchers, educators, and policy makers to reimagine new ways of thinking and speaking about students' diverse linguistic practices in moving beyond such language-separation terminology.

A translanguaging stance requires instructors to design instructional plans that are informed from the very onset by learners' diverse language practices and ways of knowing. In this way, "translanguaging pedagogies can empower students who are disempowered by English monolingualism" (Hurst \& Mona, 2017, p. 126). Flores and García (2013) remind educators that a translanguaging pedagogical stance is not restricted to instructors who are multilingual. Therefore, instructors' lack of proficiency in the languages of their students should not impede instructors from adopting a translanguaging approach to language teaching. Instructors can organize and facilitate project-based instruction and collaborative groupings for students to engage in learning practices that correspond to the learning aims of the class (García \& Li Wei, 2014). In these groupings, students can translanguage to learn and use linguistic structures and discourse required to complete a task, and support their peers' linguistic and discursive knowledge (Rajendram, 2019). In addition, instructors-even monolingual ones-may become more aware of the diversity of language practices in their own repertoires.

Our study is significant because it uncovers the various constraints that instructors in ESL programs in higher education in Canada may face in taking a translanguaging stance and implementing a translanguaging-asresource orientation in their pedagogy. What we learned from instructors 
such as Parsa, Beth, and John was that their language-as-problem orientation toward translanguaging was often caused by challenges such as the institutional pressures brought on by the commodification of English language teaching, time constraints, their sessional or part-time status in the university, and the difficulties they themselves faced learning a second or foreign language. The English-only policies that these instructors implemented were usually well-intentioned as they believed them to be the best courses of action to maximize their students' English learning outcomes while working within those constraints. In examining the effectiveness of translanguaging pedagogies, it is important to not only consider attitudes but also institutional cultures and policies (Rosiers, 2017).

Our study also suggests that despite the constraints they face, instructors reported agency in making spaces and creating opportunities for translanguaging at different points in their lesson as their students' needs require. Based on the responses to our scenario-based interview questions, which asked instructors to reflect on what they would do in various classroom scenarios, we were able to obtain examples of how instructors such as Carmen and Nancy validated the diverse language practices of their students and encouraged them to use translanguaging to enhance their learning, thereby challenging monolingual language ideologies and policies. Using scenariobased interview questions was a valuable research tool as it helped us to understand instructors' attitudes about translanguaging, as well as to get illustrative examples of the pedagogical and policy decisions they make in the classroom. This enabled us to see the unique and highly contextual ways that instructors such as Carmen and Nancy drew on translanguaging in their teaching practices, and the attitudes and orientations underlying these practices.

Further studies of translanguaging ideology as it is constructed and, at times, contested by practicing language instructors in classroom spaces is needed, especially given that one limitation of this study is in not observing instructors' policies and practices in action. Specifically, supplementary research on the use of exploratory practice (Allwright, 2003) as a form of collaborative practitioner research (Hanks, 2017) is of critical importance in developing reflexive practice among instructors. Thus, the next step in our research is to conduct classroom observations to find out how instructors act as policy makers through their pedagogical decisions, with the aim of collaborating with them to design and implement ESL pedagogy informed by a translanguaging-as-resource orientation. In conclusion, the research study presented in this article offers consideration on diversifying strategies and approaches to ESL pedagogy and classroom language policies concerning English language education in higher education contexts in Canada. 


\section{Acknowledgement}

We would like to extend our gratitude to Dr. Jeff Bale and Vijay Ramjattan for their helpful suggestions on the early drafts of our work, as well as the TESL Canada Journal Special Issue editors Dr. Saskia Van Viegen, Dr. Meike Wernicke, and Dr. Sandra Zappa-Hollman and reviewers for their thorough and substantive feedback to our article. Finally, this study would not have been possible without the willingness and time from the participants: We thank you.

\section{The Authors}

Jennifer Burton is a PhD student in Language and Literacies Education at the Ontario Institute for Studies in Education (OISE), University of Toronto. She has worked in the past as an English language teacher in Korea and Canada. Her research focuses on Teaching English to Students of Other Languages (TESOL), social justice, identity, and translanguaging in second language learning.

Shakina Rajendram completed her PhD in Language and Literacies Education at OISE, University of Toronto. She currently teaches in the Master of Teaching program at OISE. Her research focuses on translanguaging, multiliteracies, teacher education, and supporting English Language Learners.

\section{References}

Adamson, J., \& Fujimoto-Adamson, N. (2012). Translanguaging in self-access language advising: Informing language policy. SiSAL Journal, 3(1), 59-73.

Ahmad, B. H. (2009). Teachers' code-switching in classroom instructions for low English proficient learners. English Language Teaching, 2, 49-55.

Allard, E. C. (2017). Re-examining teacher translanguaging: An ecological perspective. Bilingual Research Journal, 40(2), 116-130. https://doi.org/10.1080/15235882.2017.1306597

Allwright, D. (2003). Exploratory practice: Rethinking practitioner research in language teaching. Language teaching research, 7(2), 113-141.

Azungah, T. (2018). Qualitative research: Deductive and inductive approaches to data analysis. Qualitative Research Journal, 18(4), 383-400. https://doi.org/10.1108/QRJ-D-18-00035

Babino, A., \& Stewart, M. A. (2018). Remodeling dual language programs: Teachers enact agency as critically conscious language policy makers. Bilingual Research Journal, 41(3), 272-297. https://doi.org/10.1080/15235882.2018.1489313

Bailey, E. G., \& Marsden, E. (2017). Teachers' views on recognising and using home languages in predominantly monolingual primary schools. Language and Education, 31(4), 283-306. https:// doi.org/10.1080/09500782.2017.1295981

Bale, J. (2016). In defense of language rights: Rethinking the rights orientation from a political economy perspective. Bilingual Research Journal, 39(3-4), 231-247. https://doi.org/10.1080/15 235882.2016.1224208

Bitsch, V. (2005). Qualitative research: A grounded theory example and evaluation criteria. Journal of Agribusiness, 23(1), 75-91.

Bono, M., \& Stratilaki, S. (2009). The M-factor, a bilingual asset for plurilinguals? Learners' representations, discourse strategies and third language acquisition in institutional contexts. International Journal of Multilingualism, 6(2), 207-227. https://doi. org/10.1080/14790710902846749

Brownlee, J., Walker, S., Lennox, S., Exley, B., \& Pearce, S. (2009). The first year university experience: Using personal epistemology to understand effective learning and teaching in higher education. Higher Education, 58(5), 599-618. DOI: 10.1007/s10734-009-9212-2

Canadian Bureau for International Education. (2018). Canada's performance and potential in international education: International students in Canada. Retrieved from https://cbie.ca/media/ facts-and-figures/ 
Canagarajah, S. (2011). Translanguaging in the classroom: Emerging issues for research and pedagogy. Applied Linguistics Review, 2(1), 1-28. https://doi.org/10.1515/9783110239331.1

Carroll, K. S., \& Sambolín Morales, A. N. (2016). Using university students' L1 as a resource: Translanguaging in a Puerto Rican ESL classroom. Bilingual Research Journal, 39(3-4), 248262. https://doi.org/10.1080/15235882.2016.1240114

Caruso, E. (2018). Translanguaging in higher education: Using several languages for the analysis of academic content in the teaching and learning process. Language Learning in Higher Education, 8(1), 65-90. https://doi.org/10.1515/cercles-2018-0004

Cenoz, J. (2017). Translanguaging in school contexts: International perspectives. Journal of Language, Identity \& Education, 16(4). https://doi.org/10.1080/15348458.2017.1327816

Corcoran, J. N. (2008). L1 in the L2 classroom: Framing Brazilian teacher beliefs and practices (Doctoral dissertation). University of Toronto, Toronto, Canada.

Crawford, J. (1998). Language politics in the U.S.A.: The paradox of bilingual education. Social Justice, 25(3), 50-69.

Cummins, J. (1991). Interdependence of first- and second-language proficiency in bilingual children. Language processing in bilingual children, 70-89.

Cummins, J. (2001). Negotiating identities: Education for empowerment in a diverse society (2nd ed.). Los Angeles: California Association for Bilingual Education.

Cummins, J. (2007). Rethinking monolingual instructional strategies in multilingual classrooms. Canadian Journal of Applied Linguistics/Revue canadienne de linguistique appliquée, 10(2), 221240. Retrieved from https://journals.lib.unb.ca/index.php/CJAL/article/view/19743

Cummins, J., Bismilla, V., Chow, P., Cohen, S., Giampapa, F., Leoni, L., Sandhu, P., \& Sastri, P. (2006). ELL students speak for themselves: Identity texts and literacy engagement in multilingual classrooms. Retrieved from https://www.curriculum.org/secretariat/files/ELLidentityTexts. pdf

Dagenais, D. (2013). Multilingualism in Canada: Policy and education in applied linguistics research. Annual Review of Applied Linguistics, 33, 286-301. https://doi: 10.1017/ S0267190513000056

Deroo, M. R., \& Ponzio, C. (2019). Confronting ideologies: A discourse analysis of in-service teachers' translanguaging stance through an ecological lens. Bilingual Research Journal, 1-18. https://doi-org.myaccess.library.utoronto.ca/10.1080/15235882.2019.1589604

De Jong, E. J., Li, Z., Zafar, A. M., \& Wu, C. H. (2016). Language policy in multilingual contexts: Revisiting Ruíz's "language-as-resource" orientation. Bilingual Research Journal, 39(3-4), 200-212. https://doi.org/10.1080/15235882.2016.1224988

De La Campa, J. C., \& Nassaji, H. (2009). The amount, purpose, and reasons for using L1 in L2 classrooms. Foreign Language Annals, 42, 742-759. https://doi.org/10.1111/j.19449720.2009.01052.x

Duarte, J. (2016). Translanguaging in mainstream education: A sociocultural approach. International Journal of Bilingual Education and Bilingualism. doi:10.1080/13670050.2016.1231 774.

Finch, A. (2012). Attitude change through learning. In N. M. Seel (Ed.), Encyclopedia of the sciences of learning (pp. 369-371). Boston, MA: Springer.

Flores, N., \& García, O. (2013). Linguistic Third Spaces in education: Teachers' translanguaging across the bilingual continuum. In D. Little, C. Leung, \& P. Van Avermaet (Eds.), Managing diversity in education: Key issues and some responses (pp. 243-256). Clevedon, UK: Multilingual Matters.

French, M. (2016). Students' multilingual resources and policy-in-action: An Australian case study. Language and Education, 30(4), 298-316. https://doi.org/10.1080/09500782.2015.1114628

García, O. (2009). Education, multilingualism and translanguaging in the 21st century. In A. Mohanty, M. Panda, R. Phillipson, \& T. Skutnabb-Kangas (Eds), Multilingual education for social justice: Globalising the local (pp. 128-145). New Delhi: Orient Blackswan. 
García, O. (2012). Theorizing translanguaging for educators. In C. Celic \& K. Seltzer, Translanguaging: A CUNY-NYSIEB guide for educators (pp. 1-6). Retrieved from http://www. nysieb.ws.gc.cuny.edu/files/2012/06/FINAL-Translanguaging-Guide-With-Cover-1.pdf

García, O., \& Li Wei. (2014). Translanguaging: Language, bilingualism and education. New York, NY: Palgrave Macmillan.

García, O., Johnson, S., \& Seltzer, K. (2017). The translanguaging classroom. Leveraging student bilingualism for learning. Philadelphia: Caslon.

García, O., \& Kano, N. (2014). Translanguaging as process and pedagogy: Developing the English writing of Japanese students in the US. In J. Conteh \& G. Meier (Eds.), The multilingual turn in languages education: Opportunities and challenges (pp. 258-277). North York, Canada: Multilingual Matters.

García, O., \& Leiva, C. (2014). Theorizing and enacting translanguaging for social justice. In A. Blackledge \& Angela Creese (Eds.), Heteroglossia as practice and pedagogy (pp. 199-216). Springer, Dordrecht.

Greggio, S., \& Gil, G. (2007). Teacher's and learners' use of code switching in the English as a foreign language classroom: A qualitative study. Linguagem $\mathcal{E}$ Ensino, 10(2), 371-393.

Grosjean, F. (1982). Life with two languages. Cambridge, MA: Harvard University Press.

Hanks, J. (2017). Exploratory practice in language teaching: Puzzling about principles and practices. London, UK: Springer.

Hansen, J. G. (2000). Interactional conflicts among audience, purpose, and content knowledge in the acquisition of academic literacy in an EAP course. Written communication, 17(1), 27-52. https://doi.org/10.1177/0741088300017001002

Haukås, Å. (2016). Teachers' beliefs about multilingualism and a multilingual pedagogical approach. International Journal of Multilingualism, 13(1), 1-18. https://doi.org/10.1080/14790718 .2015 .1041960

Heller, M. (2003). Globalization, the new economy, and the commodification of language and identity. Journal of Sociolinguistics, 7, 473-492. https://doi.org/10.1111/j.1467-9841.2003.00238.x

Hesson, S., Seltzer, K., \& Woodley, H. H. (2014). Translanguaging in curriculum and instruction: A CUNY-NYSIED guide for educators. Retrieved from http://www.nysieb.ws.gc.cuny.edu/ files/2014/12/Translanguaging-Guide-Curr-Inst-Final-December-2014.pdf

Hornberger, N. H., \& Link, H. (2012). Translanguaging in today's classrooms: A biliteracy lens. Theory into Practice, 51(4), 239-247. https://doi.org/10.1080/00405841.2012.726051

Hult, F. M., \& Hornberger, N. H. (2016). Revisiting orientations in language planning: Problem, right, and resource as an analytical heuristic. The Bilingual Review, 33(3), 30-49.

Hurst, E., \& Mona, M. (2017). "Translanguaging” as a socially just pedagogy. Education as Change, 21(2), 126-148. http://dx.doi.org/10.17159/1947-9417/2017/2015

Hussein, B. (2013). Teaching and learning English-as-a-second/foreign language through mother tongue: A field study. Asian Social Science, 9(10), 175-180. doi:10.5539/ass.v9n10p175

Ke, I. C., \& Lin, S. (2017). A translanguaging approach to TESOL in Taiwan. English Teaching $\mathcal{E}$ Learning, 41(1), 33-61. http://dx.doi.org/10.5539/ass.v9n10p175

Kleyn, T., \& García, O. (2019). Translanguaging as an act of transformation: Restructuring teaching and learning for emergent bilingual students. In L. de Oliveira (Ed.), The Handbook of TESOL in K-12 (pp. 69-82). Malden: Wiley

Kim, J. S. (2017). Translingual identities of international graduate students and monoglossic language ideologies in a US university ESL classroom. Korean Journal of Applied Linguistics, 33(3), 3-31.

Krefting, L. (1991). Rigor in qualitative research: The assessment of trustworthiness. The American Journal of Occupational Therapy, 43(3), 214.

Kubota, R., \& Miller, E. R. (2017). Re-examining and re-envisioning criticality in language studies: Theories and praxis. Critical Inquiry in Language Studies, 14(2-3), 129-157. https://doi.org /10.1080/15427587.2017.1290500 
Lewis, G., Jones, B., \& Baker, C. (2012). Translanguaging: Origins and development from school to street and beyond. Educational Research and Evaluation: An International Journal on Theory and Practice, 18(7), 641-654. https://doi.org/10.1080/13803611.2012.718488

Li Wei. (2014). Who's teaching whom? Co-learning in multilingual classrooms. In S. May (Ed.), The multilingual turn: Implications for SLA, TESOL, and bilingual education (pp. 167-190). New York: Routledge.

Li Wei. (2018). Translanguaging as a practical theory of language. Applied Linguistics, 39(1), 9-30. https://doi.org/10.1093/applin/amx039

Lin, A. (2013). Toward paradigmatic change in TESOL methodologies: Building plurilingual pedagogies from the ground up. TESOL Quarterly, 47(3), 521-545. https://doi.org/10.1002/ tesq. 113

Lincoln, Y. S., \& Guba, E. G. (1985). Naturalistic inquiry. Newbury Park, CA: Sage.

Lippi-Green, R. (1997). English with an accent: Language, ideology, and discrimination in the United States. New York: Routledge.

Mackinney, E. (2016). Language ideologies and bilingual realities: The case of Coral Way. In N. H. Hornberger (Ed.), Honoring Richard Ruíz and his work on language planning and bilingual education (pp. 301-315). Bristol, UK: Multilingual Matters.

Maringe, F. (2010). The meanings of globalization and internationalization in HE: Findings from a world survey. In F. Maringe \& N. Foskett (Eds.), Globalization and internationalization in higher education: Theoretical, strategic and management perspectives (pp. 17-34). London: Continuum.

Martínez-Roldán, C. M. (2015). Translanguaging practices as mobilization of linguistic resources in a Spanish/English bilingual after-school program: An analysis of contradictions. International Multilingual Research Journal, 9(1), 43-58. https://doi.org/10.1080/19313152.201 4.982442

Mazak, C. M. (2017). Introduction: Theorizing translanguaging practices in higher education. In C. Mazak \& K. S. Carroll (Eds.), Translanguaging in higher education: Beyond monolingual ideologies (pp. 1-10). Tonawanda, NY: Multilingual Matters.

McMillan, B. A., \& Rivers, D. J. (2011). The practice of policy: Teacher attitudes toward "English only." System, 39, 251-263. https://doi.org/10.1016/j.system.2011.04.011

Meiring, L., \& Norman, N. (2002). Back on target: Repositioning the status of Target Language in MFL teaching and learning. Language Learning Journal, 26, 27-35. https://doi. org/10.1080/09571730285200201

Menken, K., \& García, O. (Eds.) (2010). Negotiating language policies in schools: Educators as policy makers. New York, NY: Routledge.

Menken, K., \& Sánchez, M. T. (2019). Translanguaging in English-only schools: From pedagogy to stance in the disruption of monolingual policies and practices. TESOL Quarterly, 53(3), 714-767. https://doi.org/10.1002/tesq.513

Norton, B., \& Toohey, K. (2011). Identity, language learning, and social change. Language Teaching, 44, 412-446. https://doi.org/10.1017/S0261444811000309

Nowell, L. S., Norris, J. M., White, D. E., \& Moules, N. J. (2017). Thematic analysis: Striving to meet the trustworthiness criteria. International Journal of Qualitative Methods, 16(1), DOI: $10.1177 / 1609406917733847$

O'Leary, Z. (2017). The essential guide to doing your research project. London, UK: Sage.

Otheguy, R., García, O., \& Reid, W. (2015). Clarifying translanguaging and deconstructing named languages: A perspective from linguistics. Applied Linguistics Review, 6(3), 281-307. DOI: 10.1515/applirev-2015-0014

Otheguy, R., García, O., \& Reid, W. (2018). A translanguaging view of the linguistic system of bilinguals. Applied Linguistics Review. https://doi.org/10.1515/applirev-2018-0020

Pennycook, A. (2010). Language as a local practice. New York, NY: Routledge.

Phillipson, R. (1992). Linguistic imperialism. The Encyclopedia of Applied Linguistics, 1-7. 
Qian, X., Tian, G., \& Wang, Q. (2009). Codeswitching in the primary EFL classroom in China: Two case studies. System, 37, 719-730. https://doi.org/10.1016/j.system.2009.09.015

Rajendram, S. (2019). Translanguaging as an agentive, collaborative and socioculturally responsive pedagogy for multilingual learners (Doctoral dissertation). University of Toronto, Canada.

Ricento, T. (2005). Problems with the "language-as-resource" discourse in the promotion of heritage languages in the U.S.A. Journal of Sociolinguistics, 9(3), 348-368. https://doi. org/10.1111/j.1360-6441.2005.00296.x

Richardson, V. (1996). The role of attitudes and beliefs in learning to teach. In J. Sikula, T. Buttery, \& E. Guyton (Eds.), Handbook of research on teacher education (pp. 102-119). New York, NY: Macmillan.

Rivera, A. J., \& Mazak, C. M. (2017). Analyzing student perceptions on translanguaging: A case study of a Puerto Rican university classroom. HOW, 24(1), 122-138. http://dx.doi. org/10.19183/how.24.1.312

Rosén, L. (2017). Multilingualism and translanguaging in Swedish upper secondary school: An exploration of English teacher candidates' attitudes. Department of English, Stockholm University. Retrieved from http://www.diva-portal.org/smash/get/diva2:1109165/FULLTEXT01.pdf

Rosiers, K. (2017). Unravelling translanguaging: The potential of translanguaging as a scaffold among teachers and pupils in superdiverse classrooms in Flemish education. In B. Paulsrud, J. Rosen, B. Straszer, \& A. Wedin (Eds.), New perspectives on translanguaging and education (pp. 148-170). Bristol, UK: Multilingual Matters.

Ruíz, R. (1984). Orientations in language planning. NABE: The Journal for the National Association for Bilingual Education, 8(2), 15-34. https://doi.org/10.1080/08855072.1984.10668464

Schissel, J. L., De Korne, H., \& López-Gopar, M. (2018). Grappling with translanguaging for teaching and assessment in culturally and linguistically diverse contexts: Teacher perspectives from Oaxaca, Mexico. International Journal of Bilingual Education and Bilingualism, 1-17. https://doi.org/10.1080/13670050.2018.1463965

Sembiante, S. (2016). Translanguaging and the multilingual turn: Epistemological reconceptualization in the fields of language and implications for reframing language in curriculum studies. Curriculum Inquiry, 46(1), 45-61. https://doi.org/10.1080/03626784.2015.1133221

Shin, H. (2016). Language "skills" and the neoliberal English education industry. Journal of Multilingual and Multicultural Development, 37(5), 509-522. https://doi.org/10.1080/0143463 2.2015.1071828

Storch, N., \& Wigglesworth, G. (2003). Is there a role for the use of the L1 in an L2 setting? TESOL Quarterly, 37(4), 760-770. doi:10.2307/3588224

Tamimi Sa'd, S. H., \& Qadermazi, Z. (2015). L1 use in EFL classes with English-only policy: Insights from triangulated data. Center for Educational Policy Studies Journal, 5(2), 159-175.

Tan, C. S. (2017). Teacher beliefs on L1 use in multilingual classrooms: A New Zealand university language centre. New Zealand Studies in Applied Linguistics, 23(1), 17-32.

Tang, J. (2002). Using the L1 in the English classroom. Forum, 40(1), 36-43. https://doi.org/10.1016/j. sbspro.2012.06.251

Thomas, D. (2006). A general inductive approach for analyzing qualitative evaluation data. American Journal of Evaluation, 27(2), 237-246. doi:10.1177/1098214005283748

Wiley, T. G., \& García, O. (2016). Language policy and planning in language education: Legacies, consequences, and possibilities. The Modern Language Journal, 100(S1), 48-63. https://doi. org $/ 10.1111 / \operatorname{modl} .12303$ 